\title{
Behaviour of the transposable elements copia and $m d g 1$ in hybrids between the sibling species Drosophila melanogaster and D. simulans
}

\author{
M. P. GARCIA GUERREIRO* \\ Laboratoire de Biométrie, Génétique et Biologie des populations, URA CNRS 2055, Université Claude Bernard Lyon 1 , \\ 69622 Villeurbanne Cedex, France
}

\begin{abstract}
The behaviour of the retrotransposons copia and $m d g 1$ was analysed in hybrids between Drosophila melanogaster and $D$. simulans. Females of a highly inbred line of $D$. melanogaster were crossed with $D$. simulans males from three natural populations. The insertion site profiles for the two elements were determined in $F_{1}$ hybrid larvae by in situ hybridization to polytene chromosomes, and were compared with that of their parents. No somatic transposition events were detected after this genomic stress of interspecific hybridization for the two transposable elements concerned.
\end{abstract}

Keywords: Drosophila melanogaster, D. simulans, interspecific hybrids, transposable elements.

\section{Introduction}

Although transposable elements usually move in the germ line at a low rate, mobilization can be observed in intra- and interspecific hybrids. A well documented case is the phenomenom of hybrid dysgenesis in Drosophila in which $\mathrm{P}$ elements transpose after intraspecific crosses. Indeed the $\mathrm{P} / \mathrm{M}, \mathrm{I} / \mathrm{R}$ and hobo hybrid dysgenesis systems in $D$. melanogaster are capable of activating transposable elements, inducing sterility, gonadal atrophy and of increasing the mutation rate in $F_{1}$ progeny of intraspecific crosses between males from a natural population and females from a long established laboratory strain. Retrotransposons can also be mobilized after crosses involving laboratory or wild lines and some balancer stocks as observed in Pasyukova et al. (1988), Georgiev et al. (1990), Pasyukova \& Nuzhdin (1993) and Garcia Guerreiro \& Biémont (1995).

Genetic instabilities, measured as an increase in mutation rate, were observed in some cases. In maize, for example, the nuclear DNA content of some $F_{1}$ hybrids from crosses between different

*Present address: Departament de Genètica i Microbiologia, Unitat de Genètica, Edifici C, Universitat Autònoma de Barcelona, 08193 Bellaterra-Barcelona, Spain. inbred lines was significantly higher than their parental means. This nuclear instability depended on the parental inbred lines used in each cross (Rayburn et al., 1993).

Interspecific hybridization seems also to be associated with genomic instabilities as demonstrated mainly in plants. Price (1988) suggests that some portions of the DNA are unstable in various hybrids of the genus Microseris (Asteraceae) in such a way that these hybrids have nuclear DNA contents that differ significantly from the parental midpoint and that these instabilities can fluctuate randomly. Unusual chromosomal rearrangements were also reported in hybrids between two species of Nicotiana (Gerstel \& Burns, 1966). In Drosophila, gonadal atrophy, mutations and elevated rates of chromosomal breakage have also been observed in interspecific crosses between sibling species (Sturtevant, 1939; Naveira \& Fontdevila, 1985). In some of these Drosophila hybrids, germline transposition seems to occur (Evgen'ev et al., 1982; Labrador \& Fontdevila, 1994) at a rate similar to those reported previously in dysgenic lines of $D$. melanogaster (Fontdevila, 1993). The causes of transposition induction in interspecific hybrids are not known but the observation that syndromes characteristic of hybrid dysgenesis are common to both intraspecific and interspecific crosses suggests analogies with this phenomenon. 
Only a few data are available about the transposition rates of interspecific hybrids of Drosophila. These data concern the repleta and virilis Drosophila groups in which hybrids were checked only for germinal transpositions and the analyses have been carried out many generations after the hybridization event, sometimes 200 generations after (Evgen'ev et al., 1982).

Most of the results mentioned in the literature refer to the germline and no data are available about somatic transposition rates in $F_{1}$ interspecific hybrids of Drosophila, for which the genomic stress is expected to be very high. Nevertheless, somatically active transposable elements have been identified in D. melanogaster (Blackman \& Gelbart, 1989; Georgiev et al., 1990; Kim \& Belyaeva, 1991a,b), D. mauritiana (Hartl, 1989), Caenorhabditis elegans (Emmons \& Yesner, 1984; Moermann \& Waterson, 1989), Zea mays (Federoff, 1989), Antirrhinum majus (Coen et al., 1989) and mice (Seperack et al., 1988). Moreover, increases of somatic mutations under such stress conditions as high developmental temperatures (Getz \& van Schaik, 1991) and a reduction of the lifespan in males with $\mathrm{P}$ elements structurally modified by mutagenesis (Woodruff, 1992) have been reported. These phenomena probably result from $\mathrm{P}$ element mobilization in dysgenic hybrids.

For retrotransposable elements it is generally accepted that these elements do not undergo transposition during ontogenesis and are stable in somatic cells (Ananiev \& Ilyin, 1989; Di Franco et al., 1989). However, the results of Kim \& Belyaeva (1991b), where the gypsy element was mobilized in somatic cells of male offspring of an individual mutator strain crossed to attached- $X$ females, leave open the possibility that the somatic mobilization of retrotransposons occurs under some conditions.

I have investigated the insertion profiles of two retrotranspons, copia and $m d g 1$, in interspecific hybrids between the sibling species $D$. melanogaster and $D$. simulans. Hybrids between these two species are usually sterile or inviable (Bock, 1984) but hybrid larvae can be obtained in some cases. I found that the insertion profiles of these $F_{1}$ hybrid larvae did not show any mobilization of the two retrotransposons analysed.

\section{Materials and methods}

\section{Drosophila strains}

Line 16 is a highly inbred line of $D$. melanogaster established in 1984 (Biémont \& Aouar, 1987) and maintained by brother-sister crosses for about 100 generations and then by mass culture to avoid fertility decrease. The copia and $m d g 1$ insertion profiles showed high stability through many generations. At the time of our experiments copia elements were inserted in sites (3F), 12F, 15C, 25A, 26D, (28D), $30 \mathrm{D}, 42 \mathrm{~B}, 50 \mathrm{~A}, 57 \mathrm{C}, 67 \mathrm{E}, 75 \mathrm{~A}, 82 \mathrm{E},(90 \mathrm{~B}), 92 \mathrm{E}$, (95DE) and $100 \mathrm{~B}$, and $m d g 1$ elements in sites $3 \mathrm{~B}$, $4 \mathrm{E}, 7 \mathrm{~B}, 11 \mathrm{C}, 19 \mathrm{~F}, 25 \mathrm{~A}, 35 \mathrm{CD}, 37 \mathrm{~A}, 39 \mathrm{~F}, 59 \mathrm{E}, 53 \mathrm{C}$, $52 \mathrm{~A}, 49 \mathrm{CD}, 42 \mathrm{~B}, 41,78 \mathrm{~A}, 75 \mathrm{C}, 85 \mathrm{D}$ and $86 \mathrm{C}$ (the sites that are not present in all the larvae analysed are shown in parentheses).

The $D$. simulans populations used were recently caught in Valence (France), Madeira island, and Russia. After their arrival in the laboratory different isofemale lines were established and each was maintained by mass culture. These $D$. simulans populations all have a low copy number of copia with three fixed sites. At the time of the experiments copia elements were inserted at sites $42 \mathrm{~B}, 42 \mathrm{C}$ and $82 \mathrm{E}$ in the Valence population, $42 \mathrm{~B}, 42 \mathrm{C}$ and $82 \mathrm{E}$ in the Madeira population and $42 \mathrm{~B}, 42 \mathrm{C}, 63 \mathrm{C}$ and $82 \mathrm{E}$ in the Russian population. $m d g 1$ was not detected in any of these populations.

\section{Crosses}

Twenty $D$. melanogaster virgin females a few hours old were placed in vials with $20 \mathrm{D}$. simulans young males. I chose young flies because mating $D$. melanogaster females with $D$. simulans males is easier when flies are a few hours old than when they are 3 or more days old (Pontecorvo, 1943). Crosses were carried out at $20^{\circ} \mathrm{C}$ because low temperature $\left(18^{\circ}-22^{\circ} \mathrm{C}\right)$ makes them easier (Sturtevant, 1929; Watanabe et al., 1977; Lee, 1978). The pairs were left together for 10 days to guarantee crossing.

Of six populations of $D$. simulans tested, only males from the three populations given above hybridized with females of $D$. melanogaster to give offspring. Moreover, the degree of hybridization observed in the three populations was different: Russia and Madeira showed a higher degree of hybridization than did the Valence population.

\section{DNA probes}

I used a fragment of the $m d g 1$ element $(5.6 \mathrm{~kb})$ inserted at the HindIII site of the PBR322 plasmid (Ilyin et al., 1980; Tchurikov et al., 1980), the probe cDm 5002 containing the copia element $(5 \mathrm{~kb})$ and a genomic fragment that hybridizes in the $5 \mathrm{~A}$ region of the X chromosome (Dunsmuir et al., 1980; Levis et al., 1980). 


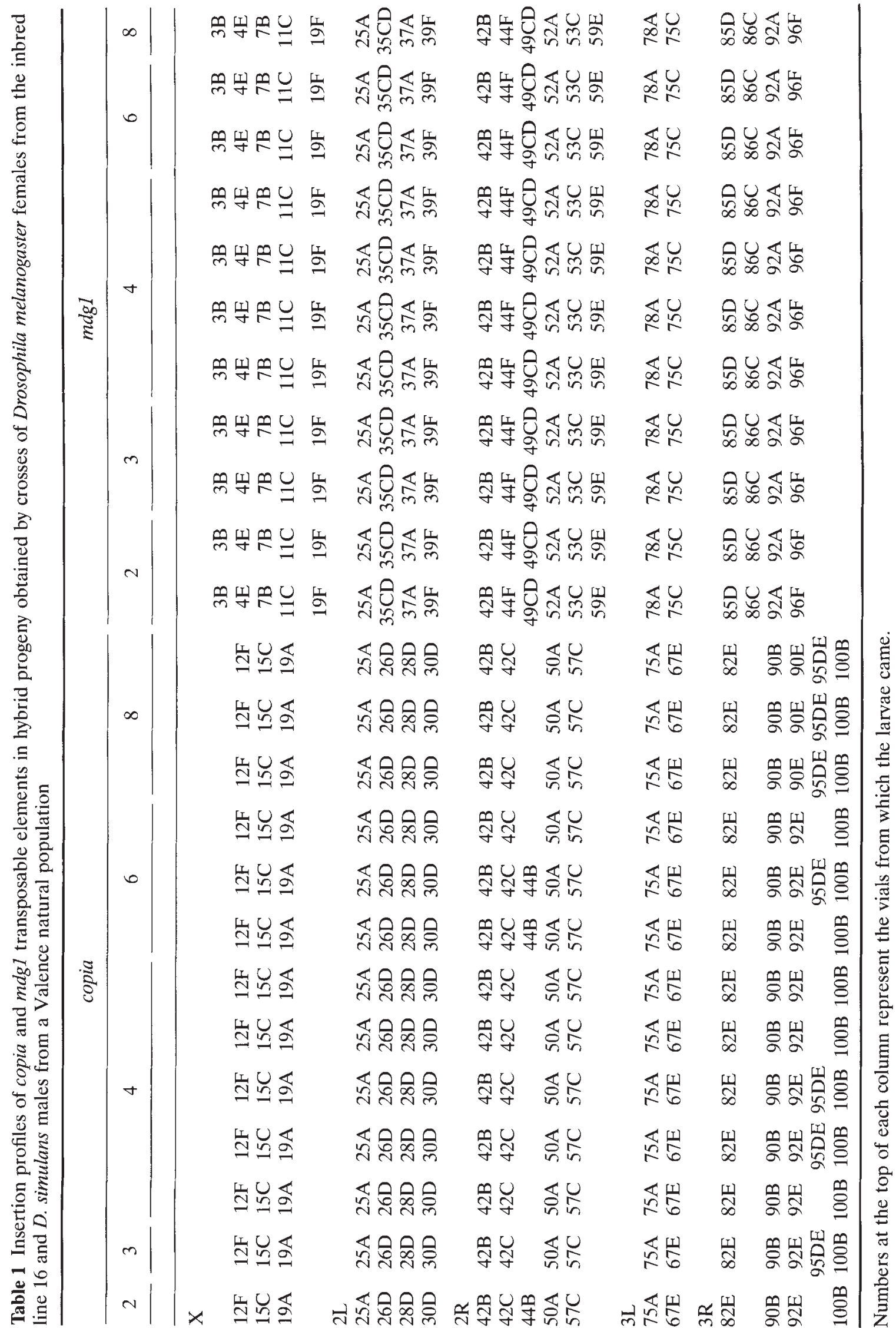




\section{In situ hybridization}

Polytene chromosome squashes from salivary glands of third instar larvae were treated with nick-translated biotinylated DNA probes as described in Biémont (1994). Insertion sites were visualized by a coupled reaction with peroxidase substrate and diaminobenzidine. The insertion pattern of transposable elements of different larvae and four different chromosome spreads on the same slides was analysed under a phase contrast microscope.

\section{Results and discussion}

Tables $1-3$ give the copia and $m d g 1$ insertion profiles of the hybrid larvae obtained after crosses of
D. simulans males with inbred $D$. melanogaster females. The copia and $m d g 1$ insertion patterns of the hybrids were the same when different chromosome spreads were compared on the same slide. Moreover, the profile of these elements is exactly the sum of the copy numbers of the two parents, as expected given that the parents were homozygous. No strong evidence of transposition events was detected for either copia or $m d g 1$ in interspecific hybrids when compared with the profiles of their parents. The only exceptions were the sites 44B (Table 1) and 44F (Tables 1-3) for the copia and $m d g 1$ elements, respectively. These sites were absent in the larvae of the inbred line 16 analysed but present in some hybrid progenies. Because these sites were present in independent progenies of the

Table 2 Insertion profiles of copia and $m d g 1$ transposable elements in hybrid progeny obtained by crosses of Drosophila melanogaster females from the inbred line 16 and $D$. simulans males from a Madeira natural population

\begin{tabular}{|c|c|c|c|c|c|c|c|c|c|c|c|}
\hline \multicolumn{3}{|c|}{ copia } & \multicolumn{9}{|c|}{$m d g l$} \\
\hline \multicolumn{3}{|c|}{1} & \multicolumn{6}{|c|}{1} & \multicolumn{3}{|c|}{2} \\
\hline \multicolumn{12}{|l|}{$X$} \\
\hline & & & $3 \mathrm{~B}$ & $3 B$ & $3 B$ & $3 \mathrm{~B}$ & $3 B$ & $3 \mathrm{~B}$ & $3 B$ & $3 \mathrm{~B}$ & $3 \mathrm{~B}$ \\
\hline $12 \mathrm{~F}$ & $12 \mathrm{~F}$ & $12 \mathrm{~F}$ & $4 \mathrm{E}$ & $4 \mathrm{E}$ & $4 \mathrm{E}$ & $4 \mathrm{E}$ & $4 \mathrm{E}$ & $4 \mathrm{E}$ & $4 \mathrm{E}$ & $4 \mathrm{E}$ & $4 \mathrm{E}$ \\
\hline $15 \mathrm{C}$ & $15 \mathrm{C}$ & $15 \mathrm{C}$ & $7 \mathrm{~B}$ & $7 \mathrm{~B}$ & $7 \mathrm{~B}$ & $7 \mathrm{~B}$ & $7 \mathrm{~B}$ & $7 \mathrm{~B}$ & $7 \mathrm{~B}$ & $7 \mathrm{~B}$ & $7 \mathrm{~B}$ \\
\hline & & & $11 \mathrm{C}$ & $11 \mathrm{C}$ & $11 \mathrm{C}$ & $11 \mathrm{C}$ & $11 \mathrm{C}$ & $11 \mathrm{C}$ & $11 \mathrm{C}$ & $11 \mathrm{C}$ & $11 \mathrm{C}$ \\
\hline & & & $19 \mathrm{~F}$ & $19 \mathrm{~F}$ & $19 \mathrm{~F}$ & $19 \mathrm{~F}$ & $19 \mathrm{~F}$ & $19 \mathrm{~F}$ & $19 \mathrm{~F}$ & $19 \mathrm{~F}$ & $19 \mathrm{~F}$ \\
\hline \multicolumn{12}{|l|}{$2 \mathrm{~L}$} \\
\hline $25 \mathrm{~A}$ & $25 \mathrm{~A}$ & $25 \mathrm{~A}$ & $25 \mathrm{~A}$ & $25 \mathrm{~A}$ & $25 \mathrm{~A}$ & $25 \mathrm{~A}$ & $25 \mathrm{~A}$ & $25 \mathrm{~A}$ & $25 \mathrm{~A}$ & $25 \mathrm{~A}$ & $25 \mathrm{~A}$ \\
\hline 26D & $26 \mathrm{D}$ & $26 \mathrm{D}$ & $35 \mathrm{C}$ & $35 \mathrm{C}$ & $35 \mathrm{C}$ & $35 \mathrm{C}$ & $35 \mathrm{C}$ & $35 \mathrm{C}$ & $35 \mathrm{C}$ & $35 \mathrm{C}$ & $35 \mathrm{C}$ \\
\hline $28 \mathrm{D}$ & $28 \mathrm{D}$ & $28 \mathrm{D}$ & $37 \mathrm{~A}$ & $37 \mathrm{~A}$ & $37 \mathrm{~A}$ & $37 \mathrm{~A}$ & $37 \mathrm{~A}$ & $37 \mathrm{~A}$ & $37 \mathrm{~A}$ & $37 \mathrm{~A}$ & $37 \mathrm{~A}$ \\
\hline 30D & $30 \mathrm{D}$ & $30 \mathrm{D}$ & $39 \mathrm{~F}$ & $39 \mathrm{~F}$ & $39 \mathrm{~F}$ & $39 \mathrm{~F}$ & $39 \mathrm{~F}$ & $39 \mathrm{~F}$ & $39 \mathrm{~F}$ & $39 \mathrm{~F}$ & $39 \mathrm{~F}$ \\
\hline \multicolumn{12}{|l|}{$2 \mathrm{R}$} \\
\hline $42 B$ & $42 B$ & $42 \mathrm{~B}$ & $42 \mathrm{~B}$ & $42 \mathrm{~B}$ & $42 \mathrm{~B}$ & $42 \mathrm{~B}$ & & $42 \mathrm{~B}$ & $42 \mathrm{~B}$ & $42 \mathrm{~B}$ & $42 \mathrm{~B}$ \\
\hline $42 \mathrm{C}$ & $42 \mathrm{C}$ & $42 \mathrm{C}$ & $42 \mathrm{C}$ & $42 \mathrm{C}$ & $42 \mathrm{C}$ & $42 \mathrm{C}$ & $42 \mathrm{C}$ & $42 \mathrm{C}$ & & & \\
\hline $50 \mathrm{~A}$ & $50 \mathrm{~A}$ & $50 \mathrm{~A}$ & $44 \mathrm{~F}$ & $44 \mathrm{~F}$ & $44 \mathrm{~F}$ & $44 \mathrm{~F}$ & $44 \mathrm{~F}$ & $44 \mathrm{~F}$ & $44 \mathrm{~F}$ & $44 \mathrm{~F}$ & $44 \mathrm{~F}$ \\
\hline \multirow[t]{4}{*}{$57 \mathrm{C}$} & $57 \mathrm{C}$ & $57 \mathrm{C}$ & $49 \mathrm{CD}$ & $49 \mathrm{CD}$ & $49 \mathrm{CD}$ & $49 \mathrm{CD}$ & $49 \mathrm{CD}$ & $49 \mathrm{CD}$ & $49 \mathrm{CD}$ & $49 \mathrm{CD}$ & $49 \mathrm{CD}$ \\
\hline & & & $52 \mathrm{~A}$ & $52 \mathrm{~A}$ & $52 \mathrm{~A}$ & $52 \mathrm{~A}$ & $52 \mathrm{~A}$ & $52 \mathrm{~A}$ & $52 \mathrm{~A}$ & $52 \mathrm{~A}$ & $52 \mathrm{~A}$ \\
\hline & & & $53 \mathrm{C}$ & $53 \mathrm{C}$ & $53 \mathrm{C}$ & $53 \mathrm{C}$ & $53 \mathrm{C}$ & $53 \mathrm{C}$ & $53 \mathrm{C}$ & $53 \mathrm{C}$ & $53 \mathrm{C}$ \\
\hline & & & $59 \mathrm{E}$ & $59 \mathrm{E}$ & $59 \mathrm{E}$ & $59 \mathrm{E}$ & $59 \mathrm{E}$ & $59 \mathrm{E}$ & $59 \mathrm{E}$ & $59 \mathrm{E}$ & $59 \mathrm{E}$ \\
\hline $\begin{array}{l}3 \mathrm{~L} \\
67 \mathrm{E}\end{array}$ & $67 \mathrm{E}$ & $67 \mathrm{E}$ & $75 \mathrm{C}$ & $75 \mathrm{C}$ & $75 \mathrm{C}$ & $75 \mathrm{C}$ & $75 C$ & $75 C$ & $75 C$ & $75 \mathrm{C}$ & $75 C$ \\
\hline $75 \mathrm{~A}$ & $75 \mathrm{~A}$ & $75 \mathrm{~A}$ & $78 \mathrm{~A}$ & $78 \mathrm{~A}$ & $78 \mathrm{~A}$ & $78 \mathrm{~A}$ & $78 \mathrm{~A}$ & $78 \mathrm{~A}$ & $78 \mathrm{~A}$ & $78 \mathrm{~A}$ & $78 \mathrm{~A}$ \\
\hline \multicolumn{12}{|l|}{$3 R$} \\
\hline \multirow[t]{2}{*}{$82 \mathrm{E}$} & $82 \mathrm{E}$ & $82 \mathrm{E}$ & $82 \mathrm{E}$ & & & & & $82 \mathrm{E}$ & $82 \mathrm{E}$ & & \\
\hline & & & $85 \mathrm{D}$ & $85 \mathrm{D}$ & $85 \mathrm{D}$ & $85 \mathrm{D}$ & $85 \mathrm{D}$ & $85 \mathrm{D}$ & $85 \mathrm{D}$ & $85 \mathrm{D}$ & $85 \mathrm{D}$ \\
\hline $90 \mathrm{~B}$ & $90 \mathrm{~B}$ & $90 \mathrm{~B}$ & $86 \mathrm{C}$ & $86 \mathrm{C}$ & $86 \mathrm{C}$ & $86 \mathrm{C}$ & $86 C$ & $86 \mathrm{C}$ & $86 \mathrm{C}$ & $86 \mathrm{C}$ & $86 \mathrm{C}$ \\
\hline $92 \mathrm{E}$ & $92 \mathrm{E}$ & $92 \mathrm{E}$ & $92 \mathrm{~A}$ & $92 \mathrm{~A}$ & $92 \mathrm{~A}$ & $92 \mathrm{~A}$ & $92 \mathrm{~A}$ & $92 \mathrm{~A}$ & $92 \mathrm{~A}$ & $92 \mathrm{~A}$ & $92 \mathrm{~A}$ \\
\hline $100 \mathrm{~B}$ & $100 \mathrm{~B}$ & $100 \mathrm{~B}$ & $96 \mathrm{~F}$ & $96 \mathrm{~F}$ & $96 \mathrm{~F}$ & $96 \mathrm{~F}$ & $96 \mathrm{~F}$ & $96 \mathrm{~F}$ & $96 \mathrm{~F}$ & $96 \mathrm{~F}$ & $96 \mathrm{~F}$ \\
\hline
\end{tabular}

Numbers at the top of each column represent the vials from which the larvae came.

(c) The Genetical Society of Great Britain, Heredity, 77, 40-46. 
Table 3 Insertion profiles of copia and $m d g 1$ transposable elements in hybrid progeny obtained by crosses of Drosophila melanogaster females from the inbred line 16 and $D$. simulans males from a Russia natural population

\begin{tabular}{|c|c|c|c|c|c|c|c|c|}
\hline \multicolumn{4}{|c|}{ copia } & \multicolumn{5}{|c|}{$m d g 1$} \\
\hline \multicolumn{3}{|c|}{1} & \multirow[t]{2}{*}{2} & \multicolumn{3}{|c|}{1} & \multicolumn{2}{|c|}{2} \\
\hline \multicolumn{8}{|l|}{$X$} & \\
\hline & & & & $3 B$ & $3 B$ & $3 B$ & $3 \mathrm{~B}$ & $3 \mathrm{~B}$ \\
\hline $12 \mathrm{~F}$ & $12 \mathrm{~F}$ & $12 \mathrm{~F}$ & $12 \mathrm{~F}$ & $4 \mathrm{E}$ & $4 \mathrm{E}$ & $4 \mathrm{E}$ & $4 \mathrm{E}$ & $4 \mathrm{E}$ \\
\hline \multirow[t]{2}{*}{$15 \mathrm{C}$} & $15 \mathrm{C}$ & $15 \mathrm{C}$ & $15 \mathrm{C}$ & $11 \mathrm{C}$ & $11 \mathrm{C}$ & $11 \mathrm{C}$ & $11 \mathrm{C}$ & $11 \mathrm{C}$ \\
\hline & & & & $19 \mathrm{~F}$ & $19 \mathrm{~F}$ & $19 \mathrm{~F}$ & $19 \mathrm{~F}$ & $19 \mathrm{~F}$ \\
\hline \multicolumn{9}{|l|}{$2 \mathrm{~L}$} \\
\hline $25 \mathrm{~A}$ & $25 \mathrm{~A}$ & $25 \mathrm{~A}$ & $25 \mathrm{~A}$ & $25 \mathrm{~A}$ & $25 \mathrm{~A}$ & $25 \mathrm{~A}$ & $25 \mathrm{~A}$ & $25 \mathrm{~A}$ \\
\hline $26 \mathrm{D}$ & $26 \mathrm{D}$ & $26 \mathrm{D}$ & $26 \mathrm{D}$ & $35 \mathrm{C}$ & $35 \mathrm{C}$ & $35 \mathrm{C}$ & $35 \mathrm{C}$ & $35 \mathrm{C}$ \\
\hline 28D & $28 \mathrm{D}$ & & $28 \mathrm{D}$ & $37 \mathrm{~A}$ & $37 \mathrm{~A}$ & $37 \mathrm{~A}$ & $37 \mathrm{~A}$ & $37 \mathrm{~A}$ \\
\hline $30 \mathrm{D}$ & $30 \mathrm{D}$ & $30 \mathrm{D}$ & $30 \mathrm{D}$ & $39 \mathrm{~F}$ & $39 \mathrm{~F}$ & $39 \mathrm{~F}$ & $39 \mathrm{~F}$ & $39 \mathrm{~F}$ \\
\hline \multicolumn{9}{|l|}{$2 \mathrm{R}$} \\
\hline $42 B$ & $42 \mathrm{~B}$ & $42 \mathrm{~B}$ & $42 B$ & $42 B$ & $42 B$ & $42 B$ & $42 B$ & $42 \mathrm{~B}$ \\
\hline $42 \mathrm{C}$ & $42 \mathrm{C}$ & $42 \mathrm{C}$ & $42 \mathrm{C}$ & $42 \mathrm{C}$ & $42 \mathrm{C}$ & & $42 \mathrm{C}$ & \\
\hline $50 \mathrm{~A}$ & $50 \mathrm{~A}$ & $50 \mathrm{~A}$ & $50 \mathrm{~A}$ & $44 \mathrm{~F}$ & $44 \mathrm{~F}$ & $44 \mathrm{~F}$ & $44 \mathrm{~F}$ & $44 \mathrm{~F}$ \\
\hline \multirow[t]{4}{*}{$57 \mathrm{C}$} & $57 \mathrm{C}$ & $57 \mathrm{C}$ & $57 \mathrm{C}$ & $49 \mathrm{CD}$ & $49 \mathrm{CD}$ & $49 \mathrm{CD}$ & $49 \mathrm{CD}$ & $49 \mathrm{CD}$ \\
\hline & & & & $52 \mathrm{~A}$ & $52 \mathrm{~A}$ & $52 \mathrm{~A}$ & $52 \mathrm{~A}$ & $52 \mathrm{~A}$ \\
\hline & & & & $53 \mathrm{C}$ & $53 \mathrm{C}$ & $53 \mathrm{C}$ & $53 \mathrm{C}$ & $53 \mathrm{C}$ \\
\hline & & & & $59 \mathrm{E}$ & $59 \mathrm{E}$ & $59 \mathrm{E}$ & $59 \mathrm{E}$ & $59 \mathrm{E}$ \\
\hline \multicolumn{9}{|l|}{$3 \mathrm{~L}$} \\
\hline \multirow[t]{2}{*}{$63 \mathrm{C}$} & $63 \mathrm{C}$ & $63 \mathrm{C}$ & $63 \mathrm{C}$ & $78 \mathrm{~A}$ & $78 \mathrm{~A}$ & $78 \mathrm{~A}$ & $78 \mathrm{~A}$ & $78 \mathrm{~A}$ \\
\hline & $67 \mathrm{E}$ & $67 \mathrm{E}$ & $67 \mathrm{E}$ & $75 \mathrm{C}$ & $75 \mathrm{C}$ & $75 \mathrm{C}$ & $75 \mathrm{C}$ & $75 \mathrm{C}$ \\
\hline $75 \mathrm{~A}$ & & & $75 \mathrm{~A}$ & & & & & \\
\hline \multicolumn{9}{|l|}{$3 \mathrm{R}$} \\
\hline & & & & & & & & $82 \mathrm{E}$ \\
\hline $82 \mathrm{E}$ & $82 \mathrm{E}$ & $82 \mathrm{E}$ & $82 \mathrm{E}$ & $85 \mathrm{D}$ & $85 \mathrm{D}$ & $85 \mathrm{D}$ & $85 \mathrm{D}$ & $85 \mathrm{D}$ \\
\hline $90 \mathrm{~B}$ & $90 \mathrm{~B}$ & $90 \mathrm{~B}$ & $90 \mathrm{~B}$ & $86 \mathrm{C}$ & $86 \mathrm{C}$ & $86 \mathrm{C}$ & $86 \mathrm{C}$ & $86 \mathrm{C}$ \\
\hline $92 \mathrm{E}$ & $92 \mathrm{E}$ & $92 \mathrm{E}$ & $92 \mathrm{E}$ & $92 \mathrm{AB}$ & $92 \mathrm{AB}$ & $92 \mathrm{AB}$ & $92 \mathrm{AB}$ & $92 \mathrm{AB}$ \\
\hline 100B & $100 \mathrm{~B}$ & $100 \mathrm{~B}$ & $100 \mathrm{~B}$ & $96 \mathrm{~F}$ & $96 \mathrm{~F}$ & $96 \mathrm{~F}$ & $96 \mathrm{~F}$ & $96 \mathrm{~F}$ \\
\hline
\end{tabular}

Numbers at the top of each column represent the vials from which the larvae came.

populations analysed, I think that the result arises from heterogeneity in the original inbred line 16 , which was not detected in the larvae analysed from the inbred line 16. In fact, the insertion polymorphism of this line was regularly checked and it was found that the transposable element insertion profile through generations showed some polymorphism.

The insertion profiles of the copia and $m d g l$ transposable elements are thus not perturbed in the $F_{1}$ hybrids resulting from crossing $D$. melanogaster females with $D$. simulans. Given that zero transposition was observed, the $95 \%$ upper confidence limit can be calculated from the Poisson distribution. If the probability of seeing zero insertion is $5 \%$, the number of new transpositions expected is $-\ln$ $(0.05)=2.9957$. Thus the upper confidence limit on the rate of transposition is $2.9957 / n$, where $n$ is the sample size. I have analysed 343 sites for copia and 532 for $m d g 1$ and for each slide I have compared the insertion profile of four spreads per slide. The total sample sizes screened on average in these experiments are thus 1372 for copia and 2128 for mdg1. The upper confidence limits are 0.00218 transpositions per element and 0.00140 transpositions per element for copia and $m d g 1$, respectively.

This result differs from the increased frequency of 
dysgenic-like events reported in hybrids between $D$. buzzatii and $D$. koepferae with relatively high frequencies of new insertions in the germline (Naveira \& Fontdevila, 1985; Labrador \& Fontdevila, 1994), and from contamination of $D$. littoralis by transposable elements from $D$. virilis after repeated backcrosses (Evgen'ev et al., 1982). In the last experiment only one new insertion was detected in hybrids analysed 200 generations after the hybridization event leaving open the possibility of a transposition a long time after hybridization. It is also hard to be sure that the new insertion site was not initially present in the original line.

It is important to note that in my case only somatic transpositions were checked because transpositions in the germline cannot be detected at the first generation of hybrid crosses and more generations would have been necessary to detect them. Unfortunately, $F_{2}$ progeny could not be analysed because the $F_{1}$ females were sterile.

As well as the germline events mentioned above, somatic ones may occur. The transposable element $T c 1$ of $C$. elegans is subject to both strain- and tissuespecific controls and in some varieties of the nematode this element is more active in somatic than in germ cells (Emmons \& Yesner, 1984). The $\mathbf{P}$ element, that is not normally active in somatic cells, can be active in special conditions of hybrid dysgenesis at $29^{\circ} \mathrm{C}$ (Getz \& van Schaik, 1991). It is known that retrotransposons are actively transcribed in somatic cells and are thus able to transpose in vivo. The first evidence of somatic transposition of retrotransposons appeared with the gypsy element which transposes in germline and somatic cells of one mutator strain (MS) (Kim \& Belyaeva, 1991b). Other transposable elements, including copia and $m d g 1$ analysed here, displayed no changes in insertion sites. These results are in agreement with the absence of mobility of the two transposable elements analysed in my study.

Crow (1984) has pointed out that limiting movement of transposable DNA to the germline prevents lethal effects, including cancer, that could occur if these elements moved in somatic tissue. There is probably a strong selective advantage to elements with repressed transposition in somatic tissues. It is suspected that in normal conditions in nature the somatic activity of transposable elements is very low or genetically suppressed (McDonald, 1990) probably because it reduces the fitness of individuals. In my experiments it is expected that the crosses between different species could have broken down the genetic system that represses somatic transpositions. As no somatic transpositions were observed it may be that these elements have no ability to transpose in somatic cells or that the genetic conditions are not suitable to promote transposition.

The causes capable of activating somatic transpositions remain obscure and more work on the behaviour of transposable elements in somatic cells under stress conditions, such as the interspecific hybridization of other Drosophila spp., is thus necessary to understand the factors able to promote somatic transposition.

\section{Acknowledgements}

I thank C. Biémont and M. Labrador for discussion and critical comments on the manuscript and one anonymous referee for his constructive remarks. This work was supported by the Centre National de la Recherche Scientifique (URA 2055) and the Association pour la Recherche sur le Cancer.

\section{References}

ANANIEV, E. V. AND ILYIN, Y. V. 1981. A comparative study of the location of mobile dispersed genes in salivary gland and midgut polytene chromosomes of Drosophila melanogaster. Chromosoma, 82, 429-435.

BIÉMONT, C. 1994. Dynamic equilibrium between insertion and excision of $\mathrm{P}$ elements in highly inbred lines from an $\mathrm{M}^{\prime}$ strain of Drosophila melanogaster. J. Mol. Evol., 39, 466-472.

BIÉMONT, C. AND AOUAR, A. 1987. Copy-number dependent transpositions and excisions of the mdg- 1 mobile element in inbred lines of Drosophila melanogaster. Heredity, 58, 39-47.

BLACKMAN, R. H. AND KELBART, W. M. 1989. The transposable element hobo of Drosophila melanogaster. In: Berg, D. E. and Howe, M. M. (eds) Mobile DNA, pp. 523-529. American Society of Microbiology, Washington, DC.

восK, I. R. 1984. Interspecific hybridization in the genus Drosophila. Evol. Biol., 18, 41-70.

COEN, E. S., ROBBINS, T. P., ALMEIDA, J., HUDSON, A. AND CARPENTER, R. 1989. Consequences and mechanisms of transposition in Antirrhinum majus. In: Berg, D. E. and Howe, M. M. (eds) Mobile DNA, pp. 413-436. American Society of Microbiology, Washington, DC.

CRow, J. F. 1984. The $P$ factor: a transposable element in Drosophila. In: Chu, E. H. Y. and Generoso, W. M. (eds) Mutation, Cancer and Malformation, pp. 257-273. Plenum Press, New York.

Di FRANCO, C., PISANO, C., DIMITRI, P. GigliotTi, S. AND JUNAKOVIC, N. 1989. Genomic distribution of copia-like transposable elements in somatic tissues and during development of Drosophila melanogaster: Chromosoma, 98, 402-410.

DUNSMUIR, P., BROREIN, W. J., Jr, SIMON, M. A. AND RUBIN, G. M. 1980. Insertion of the Drosophila transposable 
element copia generates a 5 base pair duplication. Cell, 21, 575-579.

EMMONS, S. W. AND YESNER, L. 1984. High-frequency excision of transposable element Tc1 in the nematode Caenorhabditis elegans. Cell, 36, 599-605.

EVGEN'EV, M. B., YENIKOLOPOV, G. N., PEUNOVA, N. I. AND ILYIN, Y. V. 1982. Transposition of mobile genetic elements in interspecific hybrids of Drosophila. Chromosoma, 85, 373-386.

FEDEROFF, N. V. 1989. Maize transposable elements. In: Berg, D. E. and Howe, M. M. (eds) Mobile DNA, pp. 375-412. American Society of Microbiology, Washington, DC.

FONTDEVILA, A. 1993. Genetic instability and rapid speciation: are they coupled? In: MacDonald, J. F. (ed.) Transposable Elements and Evolution, pp. 242-253. Kluwer Academic Publishers, Netherlands.

GARCIA GUerReiro, M. P. AND BIÉmont, C. 1995. Changes in the chromosomal insertion pattern of the copia element during the process of making chromosomes homozygous in Drosophila melanogaster. Mol. Gen. Genet., 246, 206-211.

GEORGIEV, P. G., KISELEV, S. L., SIMONOVA, O. B. AND GERASIMOVA, T. I. 1990. A novel transposition system in Drosophila melanogaster depending on the Stalker mobile genetic element. EMBO J., 9, 2037-2044.

GERSTEL, D. U. AND BURNS, J. A. 1966. Chromosomes of unusual length in hybrids between two species of Nicotiana. Today, 1, 41-56.

GETZ, C. AND VAN SCHAlK, N. 1991. Somatic mutation in the wings of Drosophila melanogaster females dysgenic due to $\mathrm{P}$ elements when reared at $29^{\circ} \mathrm{C}$. Mutat. Res., 248, 187-194.

HARTL, D. L. 1989. Transposable element mariner in Drosophila species. In: Berg, D. E. and Howe, M. M. (eds) Mobile DNA, pp. 531-536. American Society of Microbiology, Washington, DC.

ILYIN, Y. V., CHEMEliauskaite, V. G. AND GEORgIEV, G. P. 1980. Double-stranded sequences in RNA of Drosophila melanogaster: relation to mobile dispersed genetic genes. Nucleic Acids Res., 8, 3439-3457.

KIM, A. I. AND BELYAEVA, E. S. 1991a. Direct demonstration of the transposition of mobile element $\operatorname{mdg} 4$ in the sex and somatic cells of the unstable mutator line of Drosophila melanogaster. Dokl. Biol. Sci., 314, 595-598.

KIM, A. 1. AND BELYAEVA, E. S. 1991b. Transposition of mobile elements gypsy (mdg4) and hobo in germ-line and somatic cells of a genetically unstable mutator strain of Drosophila melanogaster: Mol. Gen. Genet., 229, 437-444.

LABRADOR, M. AND FONTDEVILA, A, 1994. High transposition rates of Osvaldo, a new Drosophila buzzatii retrotransposon. Mol. Gen. Genet., 245, 661-674.

LEE, w. L. 1978. Temperature sensitive viability of hybrids between Drosophila melanogaster and Drosophila simulans. Jap. J. Genet., 53, 339-344.
LEVIS, R., DUNSMUIR, P. AND RUBIN, G. M. 1980. Terminal repeats of the Drosophila transposable element copia: nucleotide sequence and genomic organization. Cell, 21, 581-588.

MCDONALD, J. 1990. Macroevolution and retroviral elements. Bioscience, 40, 183-191.

MOERMAN, D. G. AND WATERSON, R. H. 1989. Mobile elements in Caenorhabditis elegans and other nematodes. In: Berg, D. E. and Howe, M. M. (eds) Mobile $D N A$, pp. 537-556. American Society of Microbiology, Washington, DC.

NAVEIRA, H. AND FONTDEVILA, A. 1985. The evolutionary history of Drosophila buzzatii. IX. High frequencies of new chromosome rearrangements induced by introgressive hybridization. Chromosoma, 91, 87-94.

PASYUKOVA, E. G. AND NUZHDIN, s. v. 1993. Doc and copia instability in an isogenic Drosophila melanogaster stock. Mol. Gen. Genet., 240, 302-306.

PASYUKOVA, E. G., BELYAEVA, E. S., ILYINSKAYA, L. E. AND GVOZDEV, V. A. 1988. Outcross-dependent transpositions of copia-like mobile genetic elements in chromosomes of an inbred Drosophila melanogaster stock. Mol. Gen. Genet., 212, 281-286.

PONTECORVO, G. 1943. Hybrid sterility in artificially produced recombinants between Drosophila melanogaster and D. simulans. Proc. R. Soc. Edinb. Sect. B, 61, 385-397.

PRICE, H. J. 1988. Nuclear DNA content variation within angiosperm species. Evol. Trends Plants, 2, 53-60.

RAYBURN, A. L., BIRADAR, D. P., BULLOCK, D. G. AND McMURPHY, L. M. 1993. Nuclear DNA content in $F_{1}$ hybrids of maize. Heredity, 70, 294-300.

SEPERACK, P. K., STROBEL, M. C., CORROW, D. J., JENKINS, N. A. AND Copeland, N. G. 1988. Somatic and germ-line reverse mutation rates of the retrovirus-induced dilute coat-color mutation of DBA mice. Proc. Natl. Acad. Sci. U.S.A., 85, 189-192.

sturtevant, A. H. 1929. The genetics of Drosophila simulans. Carnegie Inst. Wash. Publ., 399, 1-62.

SturtevanT, A. H. 1939. High mutation frequency induced by hybridization. Proc. Natl. Acad. Sci. U.S.A., 25, 308-310.

TCHURIKOV, N. A., ILYIN, Y. V., SKRYABIN, K. G., ANANIEV, E. V., BAYEV, A. A., Jr, lyubomirskaya, n. v. and georgiev, g. p. 1980. General properties of mobile dispersed genetic elements in Drosophila melanogaster. Cold Spring Harbor Symp. Quant. Biol., 45, 655-665.

WATANABE, T. K., LEE, W. H., INOUE, Y. AND KAGANiSH1, M. 1977. Genetic variation of the hybrid crossability between Drosophila melanogaster and Drosophila simulans. Jap. J. Genet., 52, 1-8.

wOODRUFF, R. C. 1992. Transposable DNA elements and life history traits I. Transposition of P DNA elements in somatic cells reduces the lifespan of Drosophila melanogaster. Genetica, 86, 143-154. 